\title{
Analysis on Students' Interest in Speaking Skill
(A Descriptive Quantitative to the Eleventh Grade Students of
SMAN 1 Boyan Tanjung in the Academic Year of 2021/2022)
}

Marisa Elentri Wahyuni' ${ }^{1}$, Tri Kurniawati ${ }^{2}$, Sahrawi $^{3}$

1,2,3 Program Studi Pendidikan Bahasa Inggris, Fakultas Bahasa dan Seni, IKIP PGRI Pontianak

E-mail: marisaelentri21@gmail.com, trikurniawati.ikip@gmail.com, awihasanah@gmail.com

\section{Article Info \\ Article History \\ Received: 2021-10-09 \\ Revised: 2021-11-02}

Published: 2021-11-22

Keywords:

Analysis;

Student interest:

Skills;

Speak.

\begin{abstract}
The purposes of the research here 1) To find out the level of students' interest in speaking skill at eleventh grade of SMAN 1 Boyan Tanjung. 2) To find out students' responses in speaking skill at eleventh grade in SMAN 1 Boyan Tanjung. The research method used in this research was descriptive method. Data collection techniques used in this research resume are Direct communication technique, and Indirect Communication Techniques. Data collection tools are questionnaires and interviews. The data analysis technique used is the formula percentage by Zuldafrial (2012:226). Based on the results of the study can be concluded that in that in a manner general speaking skill at Eleventh Grade in SMAN 1 Boyan Tanjung has been low interest. More specifically can be described as follows 1) The level of students' interest in speaking skill at eleventh grade SMAN 1 Boyan Tanjung in the Academic Year of 2021/2022 which has a fairly good level of interest this is evident from the results of the acquisition of 50\% included inpretty high category. 2) Students' responses in speaking skill at Eleventh Grade in SMAN 1 Boyan Tanjung in the Academic Year of 2021/2022 is low. The low interest of students in speaking English there are several factors from them not liking English, from accuracy, fear of spelling mistakes to difficult lessons for them.
\end{abstract}

Kata kunci: Analisis;

Minat siswa; Keterampilan; Berbicara.

\begin{tabular}{l} 
Artikel Info \\
\hline Sejarah Artikel \\
Diterima: $2021-10-09$ \\
Direvisi: 2021-11-02 \\
Dipublikasi: $2021-11-22$
\end{tabular}

\begin{abstract}
Abstrak
Tujuan penelitian ini 1) Untuk mengetahui tingkat minat siswa dalam keterampilan berbicara di kelas sebelas SMAN 1 Boyan Tanjung. 2) Untuk mengetahui tanggapan siswa dalam keterampilan berbicara di kelas sebelas di SMAN 1 Boyan Tanjung. Metode penelitian yang digunakan dalam penelitian ini adalah metode deskriptif. Teknik pengumpulan data yang digunakan dalam resume penelitian ini adalah Teknik Komunikasi Langsung, dan Teknik Komunikasi Tidak Langsung. Alat pengumpulan data adalah angket dan wawancara. Teknik analisis data yang digunakan adalah formula persentase oleh Zuldafrial (2012:226). Berdasarkan hasil penelitian dapat disimpulkan bahwa secara umum keterampilan berbicara di kelas XI SMAN 1 Boyan Tanjung minatnya rendah. Lebih jelasnya dapat diuraikan sebagai berikut 1) Tingkat minat siswa terhadap keterampilan berbicara di kelas XI SMAN 1 Boyan Tanjung Tahun Pelajaran 2021/2022 yang memiliki tingkat minat yang cukup baik hal ini terlihat dari hasil perolehan sebesar 50\% termasuk kategori cukup tinggi. 2) Respon siswa dalam keterampilan berbicara siswa kelas XI SMAN 1 Boyan Tanjung Tahun Pelajaran 2021/2022 tergolong rendah. Rendahnya minat siswa dalam berbicara bahasa Inggris ada beberapa faktor dari mereka yang tidak menyukai bahasa Inggris, mulai dari ketepatan, ketakutan akan kesalahan ejaan hingga pelajaran yang sulit bagi mereka.
\end{abstract}

\section{INTRODUCTION}

Language is a characteristic of humans in communicating. Regardless of its form, every society has language as a means of communication. The spread of English as a universal language throughout the world, universal language can be defined as a language for communication between two languages, their first language is different, or two people who use English as a foreign language communicate (Harmer, 2003). English has a top priority for progress in various fields such as science, technology, finance, and business, has brought great advantages to advancing international communication. In the 2013 curriculum, students must master four language skills to learn English. The four language skills are reading, listening, speaking, and writing. These skills are interrelated and cannot stand alone. Therefore, students need to master these four skills.

Students' speaking skill can be influenced through many elements. According to Brown (2001), many elements influence in speaking. In general, there are main elements in influencing 
speech. The first is the inner element. These elements come from the themselves which include physiological factors (body organs) and physiological factors which include intelligence, attitudes, hobbies, talents, interests and motivations.

There are four aspects of speaking skill namely pronunciation, vocabulary, fluency and comprehension. In fact, many students have not mastered the four aspects of speaking skill. Based on pre-observation researchers conclude from class XI students of SMAN 1 Boyan Tanjung, namely: (1) Some students have not been able to use pronunciation properly and correctly, (2) Some students was lack in speaking practice due to weak comprehension in speaking skill, (3) Some students was still nervous to speak English because they do not master much English vocabulary. This is phenomenon often found in various school contexts for students with low interest, as experienced by class XI students of SMAN 1 Boyan Tanjung.

Students' interest in learning and participating is something important in the teaching and learning process. Interest in learning is not something that is fixed or systematic, but something that was previously not in demand, can be turned into something interesting because of certain input or new thoughts and insights and determine the high and low of an achievement in English (Ricardo, 2017). Each student has different abilities and levels in understanding new insights that affect their level of interest. However, it is often found in the learning process that students are not open about the difficulties they face. So that learning problems arise that do not get the right solution. Based on this information, the authors are interested in conducting a research entitled Analysis on Students' Interest in Speaking Skill at Eleventh Grade Students of SMAN 1 Boyan Tanjung.

\section{METHOD}

The method used in this research is the descriptive quantitative method. The population of this research is eleventh grade of SMAN 1 Boyan Tanjung totaling 87 students. Because the population in this study was less than 100 people, the researchers used the entire population as a research sample, so this study was also called the study population or total sampling. The researcher was use questionnaire and interview to collecting the data. The data was analysis used the formula percentage by Zuldafrial (2012:226).

\section{RESEARCH FINDINGS AND DISCUSSION}

The data description of the percentage of each question item and the cumulative percentage for each indicator of the student interest questionnaire are as follows:

a) Percentage of Student Interest Questionnaire Data for Indicator 1

Table 1. Percentage of Each Item of Student Interest Indicator 1Feeling Good

\begin{tabular}{rrrrrrrrrr}
\hline \multicolumn{2}{r}{ No.Item } & \multicolumn{2}{c}{ Always 4 } & \multicolumn{2}{c}{ Often 3 } & \multicolumn{2}{c}{ Seldom 2 } & \multicolumn{2}{c}{ Never 1 } \\
\hline$(+)$ & $(-)$ & F & $\%$ & F & $\%$ & F & $\%$ & F & $\%$ \\
\hline 1 & & 3 & 3,44 & 0 & 0 & 60 & 68,96 & 24 & 27,58 \\
\hline 5 & & 2 & 2,38 & 6 & 6,89 & 77 & 88,50 & 2 & 2,29 \\
\hline 2 & 28 & 32,18 & 23 & 26,43 & 12 & 13,79 & 24 & 27,58 \\
\hline 4 & 8 & 9,19 & 50 & 57,47 & 12 & 13,79 & 17 & 19,54 \\
\hline 6 & 7 & 8,05 & 14 & 16,09 & 12 & 13,79 & 54 & 62,06 \\
\hline & & &
\end{tabular}

Based on table 1, it states that students' interest in speaking English skills on the feeling good indicator, namely 11.1 states often with a total frequency of $48,21.4$ states often with a total frequency of $93,39,8$ states sometimes with a total frequency of $173,27,8$ stated never with a total frequency of 121 . Based on the percentage of student questionnaires, most of the students felt good in speaking English skills.

The overall percentage of students' interest in English speaking skills is as follows:

Table 2. Cumulative Percentage of Indicator I (Feeling Good of Indicator)

\begin{tabular}{|c|c|c|c|c|}
\hline No.Item & Score & Frequency & $\begin{array}{l}\text { Total } \\
\text { Score }\end{array}$ & $\%$ \\
\hline \multirow{6}{*}{$1,5,2,4,6$} & 4 & 48 & 192 & 20,46 \\
\hline & 3 & 93 & 279 & 29,74 \\
\hline & 2 & 173 & 346 & 36,90 \\
\hline & 1 & 121 & 121 & 12,90 \\
\hline & Total & 435 & 938 & 100 \\
\hline & Highest Score & \multicolumn{3}{|c|}{4} \\
\hline \multicolumn{2}{|c|}{ Number of statements } & \multicolumn{3}{|c|}{5} \\
\hline \multicolumn{2}{|c|}{ Number of Respondents } & \multicolumn{3}{|c|}{87} \\
\hline \multicolumn{2}{|r|}{ Maximum Score } & \multicolumn{3}{|c|}{1740} \\
\hline \multicolumn{2}{|r|}{ Percentage } & \multicolumn{3}{|c|}{$53,9 \%$} \\
\hline
\end{tabular}

Based on the table above, it states that 87 respondents and 5 questions for the first indicator obtained a total frequency of 435 for all alternative answers, a total score of 938, and a maximum score of 1740 The maximum score was obtained from the highest score $\mathrm{x}$ number of questions $x$ number of respondents for one indicator. The results of the calculation of the percentage obtained 53.9\%. This means that overall students are classified as having highcategoryon feeling good of indicator. 
b) Data on the percentage of Student Interest for Indicator II

Table 3. Percentage of Each Student questionnaire Item Indicator III

\begin{tabular}{rrrrrrrrrr}
\hline \multicolumn{2}{r|}{ No.Item } & \multicolumn{2}{c}{ Always 4 } & \multicolumn{2}{c}{ Often 3 } & \multicolumn{2}{c}{ Seldom 2 } & \multicolumn{2}{c}{ Never 1 } \\
\hline$(+)$ & $(-)$ & F & $\%$ & F & $\%$ & F & $\%$ & F & $\%$ \\
\hline 7 & & 6 & 3,44 & 8 & 9,19 & 39 & 44,82 & 34 & 39,08 \\
\hline & 8 & 4 & 32,18 & 33 & 37,93 & 7 & 8,04 & 43 & 49,42 \\
\hline 12 & 9 & 9,19 & 26 & 29,88 & 26 & 29,88 & 26 & 29,88 \\
\hline Jumlah & 19 & 14,9 & 67 & 25,7 & 72 & 27,6 & 103 & 39,5 \\
\hline
\end{tabular}

Based on table 3 it states that students' interest in English speaking skills on the indicators of interest, namely 14.9 states often with a total frequency of $19,25.7$ states often with a total frequency of $67,27.6$ states sometimes with a total frequency of $72,39,5$ stated never with a total frequency of 103. Based on the percentage of the questionnaire, most of the students gave an interest in English speaking skills.

The overall percentage of students' interest in English speaking skills is as follows:

Table 4. Cumulative Percentage of Indicator II (Interest of Indicator)

\begin{tabular}{rcccc}
\hline \multirow{2}{*}{ No.Item } & \multirow{2}{*}{ Score } & Frequency & $\begin{array}{c}\text { Total } \\
\text { Score }\end{array}$ & \multirow{2}{*}{$\%$} \\
\hline \multirow{3}{*}{$1,5,2,4,6$} & 19 & 76 & 7,28 \\
\cline { 2 - 5 } & 4 & 67 & 201 & 25,68 \\
\cline { 2 - 5 } & 3 & 72 & 144 & 27,58 \\
\hline \multicolumn{2}{c}{ Total } & 261 & 524 & 103 \\
\hline Highest Score & 4 \\
\hline Number of statements & 3 \\
\hline Number of Respondents & \multicolumn{3}{c}{87} \\
\hline Maximum Score & \multicolumn{3}{c}{1044} \\
\hline Percentage & $50,2 \%$ \\
\hline
\end{tabular}

Based on the table above, it states that 87 respondents and 3 questions for the first indicator obtained a total frequency of 261 for all alternative answers, a total score of 524, and a maximum score of 1044 . The maximum score was obtained from the highest score $\mathrm{x}$ number of questions $x$ number of respondents for one indicator. The results of the calculation of the percentage obtained $50.2 \%$. This means that overall students are classified as having low categoryon interest of indicator.

c) Data on the percentage of Student Interest Questionnaire in Speaking Skills

Table 5. Percentage of Each Student Questionnaire Item Indicator III

\begin{tabular}{rrrrrrrrrr}
\hline No.Item & \multicolumn{2}{c}{ Always 4 } & \multicolumn{2}{c}{ Often 3 } & \multicolumn{2}{c}{ Seldom 2 } & \multicolumn{2}{c}{ Never 1 } \\
\hline$(+)$ & $(-)$ & F & $\%$ & F & $\%$ & F & $\%$ & F & $\%$ \\
\hline 3 & 4 & 4,59 & 2 & 2,29 & 42 & 48,27 & 39 & 44,82 \\
\hline 9 & 1 & 1,14 & 4 & 4,59 & 34 & 39,08 & 48 & 55,17 \\
\hline 13 & 9 & 10,34 & 13 & 14,94 & 38 & 43,67 & 47 & 54,02 \\
\hline 14 & 9 & 10,34 & 11 & 12,64 & 65 & 74,71 & 2 & 2,29 \\
\hline 15 & 5 & 5,74 & 8 & 9,19 & 43 & 49,42 & 31 & 35,63 \\
\hline
\end{tabular}

\begin{tabular}{rrrrrrrrr}
\hline 11 & 3 & 3,44 & 36 & 41,37 & 33 & 37,93 & 15 & 17,24 \\
\hline 16 & 1 & 1,14 & 6 & 6,89 & 3 & 3,44 & 77 & 88,59 \\
\hline 17 & 4 & 4,59 & 40 & 45,97 & 33 & 37,93 & 10 & 11,50 \\
\hline 18 & 8 & 9,19 & 43 & 49,42 & 5 & 5,74 & 31 & 35,63 \\
\hline Jumlah & 44 & 5,61 & 163 & 20,81 & 296 & 37,80 & 300 & 38,32 \\
\hline
\end{tabular}

Based on table 5 it states that students' interest in speaking English skills on the indicator of The Attention to learning is 5.61 states often with a total frequency of $44,20.81$ states often with a total frequency of 163 , 37.80 states sometimes with a total frequency of $296,38.32$ stated never with a frequency of 300. Based on the percentage of the questionnaire, most of the students gave the Attention to learning in English speaking skills.

The overall percentage of the Attention to learning students' interest in English speaking skills is as follows:

Table 6. Cumulative Percentage of Indicator III (The Attention to learning of Indicator)

\begin{tabular}{ccccc}
\hline \multirow{2}{*}{ No.Item } & Score & Frequency & $\begin{array}{r}\text { Total } \\
\text { Score }\end{array}$ & \multirow{2}{*}{$\%$} \\
\hline \multirow{3}{*}{$3,9,13,14,15,11,17,18$} & 4 & 44 & 176 & 11,30 \\
\cline { 2 - 5 } & 3 & 163 & 489 & 31,41 \\
\cline { 2 - 5 } & 2 & 296 & 592 & 38,02 \\
\cline { 2 - 5 } & 1 & 300 & 300 & 19,27 \\
\hline Total & 803 & 1555 & 100 \\
\hline Highest Score & \multicolumn{3}{c}{8} \\
\hline Number of statements & \multicolumn{3}{c}{3132} \\
\hline Mumber of Respondents & $50 \%$ \\
\hline Paximum Score & & \\
\hline
\end{tabular}

Based on the table above, it is stated that 87 respondents and 8 questions for the first indicator obtained a total frequency of 803 for all alternative answers, a total score of 1555 , and a maximum score of 3132 . The maximum score was obtained from the highest score $\mathrm{x}$ number of questions $x$ number of respondents for one indicator. The results of the calculation of the percentage obtained 50\%. This means that overall students are classified as having low categoryon the Attention to learning indicator.

d) Data on the percentage of Student Interest Questionnaire in Speaking Skills

Table 7. Percentage of Each Student Questionnaire Item Indicator IV

\begin{tabular}{|c|c|c|c|c|c|c|c|c|}
\hline No.Item & \multicolumn{2}{|c|}{ Always 4} & \multicolumn{2}{|c|}{ Often 3} & \multicolumn{2}{|c|}{ Seldom 2} & \multicolumn{2}{|c|}{ Never 1} \\
\hline$(+)(-)$ & $\mathrm{F}$ & $\%$ & $\mathrm{~F}$ & $\%$ & $\mathrm{~F}$ & $\%$ & $F$ & $\%$ \\
\hline 19 & 4 & 4,59 & 14 & 16,09 & 41 & 47,12 & 28 & 32,18 \\
\hline 20 & 11 & 12,64 & 6 & 6,89 & 12 & 13,79 & 58 & 66,67 \\
\hline Jumlah & 15 & 8,62 & 20 & 11,49 & 53 & 30,5 & 86 & 49,4 \\
\hline
\end{tabular}

Based on table 7 it states that students' interest in speaking English skills on the indicator of the participation in learning, 
namely 8.62 states often with a total frequency of $15,11.49$ states often with a total frequency of 20, 30.5 states sometimes with a total frequency of $53,49.4$ stated never with a total frequency of 86. Based on the percentage of the questionnaire, most of the students gave the participation in learning in English speaking skills.

The overall percentage of the participation in learning students' interest in English speaking skills is as follows:

Table 8. Cumulative Percentage of Indicator IV (participation in learning of Indicator)

\begin{tabular}{|c|c|c|c|c|}
\hline No.Item & Score & Frequency & $\begin{array}{l}\text { Total } \\
\text { Score }\end{array}$ & $\%$ \\
\hline \multirow{6}{*}{19,20} & 4 & 15 & 60 & 19,23 \\
\hline & 3 & 20 & 60 & 19,23 \\
\hline & 2 & 53 & 106 & 33,97 \\
\hline & 1 & 86 & 86 & 27,56 \\
\hline & Total & 174 & 312 & 100 \\
\hline & Highest Score & \multicolumn{3}{|c|}{4} \\
\hline \multicolumn{2}{|c|}{ Number of statements } & \multicolumn{3}{|c|}{2} \\
\hline \multicolumn{2}{|c|}{ Number of Respondents } & \multicolumn{3}{|c|}{87} \\
\hline \multicolumn{2}{|r|}{ Maximum Score } & \multicolumn{3}{|c|}{696} \\
\hline & Percentage & \multicolumn{3}{|c|}{$44,8 \%$} \\
\hline
\end{tabular}

Based on the table above, it states that 87 respondents and 3 questions for the first indicator obtained a total frequency of 174 for all alternative answers, a total score of 312 , and a maximum score of 696 . The maximum score was obtained from the highest score $\mathrm{x}$ number of questions $x$ number of respondents for one indicator. The results of the calculation of the percentage obtained $44.8 \%$. This means that overall students are classified as having low categoryon the indicator of the participation in learning.

e) Data on the percentage of Student Interest Questionnaire in Speaking Skills

Table 9. Percentage of Each Student Questionnaire Item Indicator V

\begin{tabular}{crrrrrrrrr}
\hline \multicolumn{2}{c}{ No.Item } & \multicolumn{2}{c}{ Always 4 } & \multicolumn{2}{c}{ Often 3 } & \multicolumn{2}{c}{ Seldom 2 } & \multicolumn{2}{c}{ Never 1 } \\
\hline$(+)$ & $(-)$ & $\mathrm{F}$ & $\%$ & $\mathrm{~F}$ & $\%$ & $\mathrm{~F}$ & $\%$ & $\mathrm{~F}$ & $\%$ \\
\hline 10 & 3 & 3,44 & 5 & 0 & 27 & 31,03 & 52 & 59,77 \\
\hline \multicolumn{2}{c}{ Jumlah } & 3 & 3,44 & 5 & 0 & 27 & 31,03 & 52 & 59.77 \\
\hline
\end{tabular}

Based on table 9, it states that students' interest in speaking English skills on the indicator of desire and awareness in learning is 3.44 stating often with a frequency of 3,0 stating often with a total frequency of $0,31.03$ stating sometimes with a total frequency of 27, 59.77 stated never with a total frequency of 52. Based on the percentage of the questionnaire, most of the students gave desire and awareness in learning in English speaking skills.
The overall percentage of desire and awareness in learning students' interest in English speaking skills is as follows:

Table 10. Cumulative Percentage of Indicator V (desire and awareness in learning of Indicator)

\begin{tabular}{|c|c|c|c|c|}
\hline No.Item & Score & Frequency & $\begin{array}{l}\text { Total } \\
\text { Score }\end{array}$ & $\%$ \\
\hline \multirow{6}{*}{10} & 4 & 3 & 12 & 9,02 \\
\hline & 3 & 5 & 15 & 11,28 \\
\hline & 2 & 27 & 54 & 40,60 \\
\hline & 1 & 52 & 52 & 39,09 \\
\hline & Total & 87 & 133 & 100 \\
\hline & Highest Score & \multicolumn{3}{|c|}{4} \\
\hline \multicolumn{2}{|c|}{ Number of statements } & \multicolumn{3}{|c|}{1} \\
\hline \multicolumn{2}{|c|}{ Number of Respondents } & \multicolumn{3}{|c|}{87} \\
\hline \multicolumn{2}{|r|}{ Maximum Score } & \multicolumn{3}{|c|}{348} \\
\hline \multicolumn{2}{|r|}{ Percentage } & \multicolumn{3}{|c|}{$38,2 \%$} \\
\hline
\end{tabular}

Based on the table above, it states that 87 respondents and 1 question for the first indicator obtained a total frequency of 87 for all alternative answers, a total score of 133 , and a maximum score of 348 . The maximum score was obtained from the highest score $\mathrm{x}$ number of questions $x$ number of respondents for one indicator. The results of the calculation of the percentage obtained 38.2\%. This means that overall students are classified as having low categoryon thedesire and awareness in learningof indicators.

Students' responses in speaking skill at Eleventh grade in SMAN 1 Boyan Tanjung in every school context, having students with high interest is certainly the hope of the teachers. In addition to making it easier for teachers to guide students to study at school, having a high interest of course also has a good response, especially speaking skills in English, because students have the initiative and encouragement from within for maximum achievement. However, such idealized contexts are generally rare. In fact, it is often found in various school contexts where students have low interest and high student interest, as happened in a SMA Negeri 1 Boyan Tanjung.

Based on the results of interviews with class XI students of SMA Negeri 1 Boyan Tanjung about the response of students' interest in speaking English as said Winda kadang-kadang ia menyukai bahasa inggris (interview date 29 Juli 2021), Adiel tidak suka belajar berbicara (interview date 27 Juli 2021) same thing said Selfi ia tidak menyukai belajar berbicara karena tidak terlalu pintar dalam belajar berbahasa.Apart from them not liking learning to speak, there are motivations that arise in learning English, especially in 
speaking as Selfi said belajar berbahasa tidak hanya belajar bahasa Indonesia akan tetapi penting juga untuk kita mengetahui bahasa asing terutama bahasa inggris (interview 27 Juli 2021).

Another thing to Say Eva ia mempunyai motivasi dalam belajar bahasa inggris, saya ingin menggunakan bahasa inggris kalau misalnya ada peluang ke luar kota kalau bertemu orang asing dan mereka nanya sesuatu dengan mudah kita menjawabnya dengan menggunakan Bahasa inggris dengan fasih dan benar (interview date 27 Juli 2021). Rio Salah satu faktor pendorong saya dalam belajar bahasa inggris karena kesempatan kita untuk membuka bisnis apa lagi di bagian ekspor, kita harus betulbetul menguasai bahasa inggris dengan Fasih dan benar. Bahasa inggris juga merupakan bahasa Internasional yang paling sering digunakan di banyak negara. Sehingga kita dapat lebih mudah berkomunikasi dengan orang-orang di berbagai negara. Oleh karena itu, saya termotivasi untuk terus belajar dan mendalami bahasa inggris. Harapan saya kedepannya saya dapat memahami dan menguasai pelajaran yang di berikan. Saya juga berharap bahwa saya dapat menggunakan bahasa nggris dengan baik dalam berkomunikasi. Membangun relasi, bukan hanya di dalam kelas tetapi juga di luar kelas. Saya harap semangat saya kedepannya tetap sama seperti semangat saya dalam belajar di awal (interview date 27 Juli 2021).

With the motivation to motivate them to have an interest in learning to speak English as said Jumi ia menyukai karena kita bisa mengetahui bahasa asing (interview date 29 Juli 2021). So is menurut Dwi ia juga menyukai tapi harus banyak belajar lagi soal mata pelajaran bahasa inggris (interview date 27 Juli 2021). Julia juga mengatakan suka karena kalau saya bisa bahasa inggris suatu hari saya bertemu dengan orang inggris,saya bisa berbicara dengan mereka (interview date 29 Juli 2021). Eva juga mengatakan suka belajar bahasa inggris dikarenakan gaya bicara dan ucapannya sangat menarik (interview date 27 Juli 2021).

Motivation is also a role to achieve interest in learning to speak English, although they do not yet have the right accuracy in speaking
English, at least students already have an interest in learning English. As said Eva dalam hal akurasi bicara dalam berbahasa inggris saya belum sepenuhnya bisa berbahasa inggris dan menurut saya belajar berbahasa inggris itu sulit (interview date 27 Juli 2021). Selfi akurasi bicara masih belum tepat (interview date 27 Juli 2021). ). Furthermore Rio akurasi dalam berbicaranya belum sepenuhnya bisa berbahasa inggris dan menurut saya belajar berbahasa inggris itu sulit(interview date 27 Juli 2021). Selain akurasi yang masih kurang tepat yang dikatakan Adiel alasan ia tidak ingin berbicara bahasa inggris karena sulit untuk diucapkan (interview date 27 Juli 2021). Then Mira also say because iatidak bisa berbahasa inggris (interview date 26 Juli 2021. Dwisay because dipikiran saya bahasa inggris adalah mata pelajaran yang sulit dan tidak mudah di pahami (interview date 27 Juli 2021). Winda juga mengatakan tidak ingin berbicara bahasa inggris karena sulit dimengerti (Interviewe date 29 Juli 2021).

Based on the results of these interviews, it can be concluded that the response of students' interest in speaking English is still low. The low interest of students in speaking English there are several factors from them not liking English, from accuracy, fear of spelling mistakes to difficult lessons for them, these reasons cannot be separated from the role of the teacher in order to increase students' interest in English speaking skills.

Based on the analysis conducted by students' interest in class XI SMAN 1 students, the feeling good indicator has a percentage of $53.9 \%$ in the category of having high interest. Indicator of interest with a percentage of $50.2 \%$ in the category of having low interest. Indicator of the attention to learning with an indicator of $50 \%$ with a low category on attention to learning.The next indicator is participation in learning with a percentage of $44.8 \%$ in the low category, the fifth indicator is desire and awareness in learning with a percentage of $38.2 \%$ in the low category. Overall students' interest in speaking skills has low interest.

The results of (2016: 32) research showed the coefficient of determination is that learning outcomes are influenced by interest in learning by $21.77 \%$, the remaining $78.23 \%$ is influenced by other factors. Interest in learning is defined if 
studnts' who is interested in a lesson was have a sense of interest in the lesson. Students will study hard and continue to understand all the domain related, they will follow the lessons with enthusiasm without any burden for them. Thus, students will be mindful of learning, if their and their minds are focused on what they are learning. Base on interviews with class XI students of SMA Negeri 1 Boyan Tanjung from the list of questions made, they generally have low interest. So, it would be better if there was further research on the importance of students' interest in learning English, especially speaking skills.

\section{CONCLUSIONS}

Based on the results of the study, it can be said that in general the students' interest in speaking skills ateleventh gradeof SMAN 1 Boyan Tanjung are low category. For more specifically it can be described as follows: feeling good of indicator with a percentage of $53.9 \%$, interest of indicator $50.2 \%$, Attention to learning of indicator $50 \%$, participation in learning of indicator $44.8 \%$, desire and awareness in learning of indicator $38.2 \%$. For students' responses onstudents' interest in speaking skills at eleventh grade of SMAN 1 Boyan Tanjung in theacademic yearof $2021 / 2022$ are relatively low category. This is seen from the factors of those who do not like English, ranging from accuracy, fear of spelling errors, for a difficult lesson for them.

\section{BIBLIOGRAPHY}

Arikunto, S. (2019). Prosedur penelitian: Suatu pendekatan praktik. Jakarta:Rineka Cipta.
Ary, D., Jacobs, L.C., \& Sorensen, C., Walker, D. (2002). Introduction to research in education. USA: Wadsworth.

Astuti, D.S. (2016). Hubungan penguasaan kosakata dan minat dengan keterampilan membaca. Jurnal Pendidikan Bahasa,5(2),173-187. doi.org/10.31571/bahasa.v5i2.323.

Brown, H.D. (2001). Teaching by principle:an interactive approach to language pedagogy. New York: Longman.

Harmer, J, (2003). The practice of english language, (3rd edition). New York: Longman.

Nurhasanah, S.(2016). Learning interest as determinant student learning outcomes.Jurnal pendidikan manajemen perkantoran, 1 (1), 128-135. doi.org/10.17509/jpm.v1i1.3264.

Ricardo. (2017). The impacts of students' learning interest and motivation on their learning outcomes. Jurnal pendidikan perkantoran. 2(2), 188-201. doi.org/10.17509/jpm.v2i2.8108.

Svetlana, C.B., Bolotin, M.M., \& Lissitsa, S. (2016).Examination of factors predicting secondary students' interest in tertiary STEM education. International Journal of Science Education, 1(2),1-25. doi.org/10.1080/09500693.2016.1143137 